\title{
Financing Education in Nigeria for National Development
}

\author{
Ukpong, D. E., Nseabasi, A. S., and Uneh, C. A. \\ Department of Educational Foundations, Faculty of Education, University of Uyo, Uyo \\ Correspondence: davidukpong695@yahoo.com
}

\begin{abstract}
The expansion and funding of education have attracted much interest both in the past and in recent times. Increased concern about rising costs is leading to the search and ways of reducing costs and expenditure. Economists have become interested in the sources of funding education, and are currently suggesting alternative avenues for financing the industry. The problem facing the education sector has led to many agitations for increased funding of education by labour unions and other concerned bodies in Nigeria higher education system. These unions have been consistent with their demands, citing decay of infrastructural facilities in our educational institutions, from primary to tertiary levels, vis-à-vis poor library facilities, empty laboratories, congestion in lecture halls and student hostels. They have in different forms and releases, charged the various governments of disobeying the UNESCO directive that member countries of the United Nations should allocate a minimum of 26 percent of their annual budgets to the educational sector. The challenge here is to fashion out appropriate funding initiatives that will generate benefit to the household, firm, the government and the rest of the world. Consequently, the study examines the Nigeria education financing including investment and accountability.
\end{abstract}

Keywords: Funding Education; National Development; Annual Budget; Education Development

DOI: $10.7176 / \mathrm{JPID} / 51-06$

Publication date: November $30^{\text {th }} 2019$

\section{Introduction}

In both developed and developing countries, education is no longer seen as an ordinary consumer commodity required for the cultivation of habits that conform to the norms of the society, but also as an important kinds of investment in a nation's future and an instrument for national development. This is premised on the understanding that whatever is invested in the education enterprise is bound to yield some dividends, just like any other business concern. These dividends are called returns on that particular investment. Education is concerned with the transmission of knowledge and acquisition of skills that will enable the individual not only to survive in the society, but also to contribute to the development of the society (Bell Gam, 2003). Hence the functionality of our educational systems, to a large extent, depends on adequate funding of all the levels of education by the governments (local, state and federal) and other stakeholders. Education financing, thus connotes the means employed to provide funds for the expenditure profile involved in the staffing, equipping, and maintenance of educational institutions. Education funding as an aspect of public finance embraces all features of funding of education including the sources of funding and how the money earmarked for education is spent especially for the purchase of goods and the services of men and materials. Education is an expensive social service and therefore requires adequate financial provision from all stakeholders including government for successful implementation of all identified educational programme adopted for implementation. Education is expensive because money is needed to hire, train and pay teachers, provide and maintain facilities like classrooms, laboratories, studios, workshops and replace consumable equipment on a continuous basis. One of the greatest problems facing Nigerian tertiary education is that of limited financial resources in the face of increasing responsibility and dwindling economy. Education is expensive while ignorance is costly (Fagbulu, 2003). Education has given ample proof of its viability over the centuries and of its ability to induce change and progress in society. It has never been in doubt that investment in education is eroded towards the development of high-level human power. The vision of Nigeria as a leader in Africa has the great potential of being realized to the extent that education is accorded a rightful place in the regime of funding of the education sector (Okebukola, 2003).

The history of education in Nigeria dates back to the colonial period. Then and up till about two decades ago, education was funded from foreign aids, fees and government grants. As a result of the "oil boom", the federal government took over all responsibilities for funding education putting aside foreign aids and fees. But things have changed. The political, social, and economic instability have tended to change this arrangement, creating stress in almost every sphere of Nigerian life (Ajibade, 1988). These stresses have made funding of higher education problematic.

The need for both the government, institutions of higher learning and people of this country to explore the possibility of generating funds for education through fees, extra mural programmes, letting of institutional facilities, research, benefactions, endowments, establishment of institutional companies, alumni association etc. Although these methods have their limitations, they are worth trying, since the nation is in urgent need of funds for obtaining her technological emancipation through her institutions of higher learning which comes under the scope of education financing. This concept, education financing refers to the process of sourcing, allocating and 
managing public school revenues in the production of education services for the attainment of educational objectives (Okunamiri, 2001). It deals with the critical examination of the cost versus expenditure in the production of educational services (Okunamiri, 2002)

The Academic Staff Union of Universities (ASUU) and its counterparts in the polytechnic (ASUP) has called out their members for strike actions for periods ranging between two weeks, and six months. these unions have been consistent with their demands, citing decay of infrastructural facilities in our educational institutions, from primary to tertiary levels, vis-à-vis poor library facilities, empty laboratories, congestion in lecture halls and student hostels, lack of sufficient office space for lecturers, lack of funds to carry out research and organize conferences and seminars, and of course poor pay package for the staff of these institutions (Ekong, 2003). They have in different releases, charge for various government (both federal and state) of disobeying the UNESCO directive that member countries of the United Nations should allocate a minimum of 26 percent of their annual budgets to the educational sector.

The National Policy on Education (2004:4) stated explicitly that "Education is an instrument par excellence for affecting national development", in response to this recognition. Nwagwu (2003) in Oboegbulem (2005) noted that the federal government allocated $1.8 \%$ of federal budget to education in $2003,5 \%$ in $2002,6.9 \%$ in 2001 and $11 \%$ in the 1999 budget. This decrease in allocation shows that the Federal Government education budget may not be sufficient to carter for the public institution programmes. Ironically, government use to emphasize that:

- Education is an investment in human capital

- Education is an instrument for achieving national development and stability

- Education is the key to creation of wealth

- Education determines the quality of life of any nation

- Education is the pathway to social mobility

The centrality of education as the driving force to development was underscored by President Obasanjo in the presentation of 2004 budget which gave education and health sectors highest allocation stating "this is to send sharp signals that these two sectors are fundamental to future growth, wealth creation, poverty reduction and enhanced living critical to the attainment of Millennium Development Goals (MDGs)". Though education and health sectors are both important sectors in the economy, one must not forget that education is more pervading. An educated person is more able to have a firm control of his/her health, manage family health, increase productivity and participate actively and meaningfully in governance. The centrality of the education sector therefore places a burden on each and every citizen to see that the sector succeeds. If the matter is funding, our commitment is to provide the fund, monitor its use and ensure effectiveness and efficiency. What are funds used for in the education sector?

- Where do the funds come from?

- What is the volume of funds available for education sector?

- What have been the consequences of inadequate funding of education?

- What are the constraints to adequate funding of education?

- What strategies may be adopted to improve education funding in Nigeria?

\section{Uses of Education Funds in Nigeria}

The first thing that occurs to an ordinary person when educationists talk about funds for education is salaries. Yes, but funds for education go into various capital and recurrent expenditure beside salaries. Education is organized as formal and non-formal systems. Formal education is that organized for learners within the primary, secondary and tertiary school age with prescribed curricula for each stage. Non-formal education often referred to as adult or continuing education is organized especially for learners to acquire specific knowledge and skills in order to have a more fulfilled life. In discussing funding for education, these two groups must be kept in mind, learners at primary school level, secondary and tertiary education level as well as learners in the non-formal education sector.

Education at whatever formal or non-formal level takes place in designated centres or schools with teachers/instructors taking learners through planned learning activities to achieve stated educational goals. One thing is certain; there are basic requirements for the achievement of the goals stated for each level of education. These include infrastructure, equipment, instructional/teaching materials, resources for learning, personnel to implement education programmes - teachers and support staff. For clearer understanding, it is important to provide a little more detail on infrastructure. Infrastructure refers to buildings, housing, classrooms, lecture rooms/halls/theatre, laboratories, workshops, administrative blocks with appropriate furniture and workbenches. Equipment includes science laboratory/workshop equipped for various forms of practical consumable and nonconsumable materials for work/skills development, photocopiers, computers, communication equipment for administrative work. 
To meet the basic needs in education sector much fund is required. Why much? For educational institutions alone about 106 public Universities, 97 Polytechnics, 65 Colleges of Education, hundreds of secondary/technical schools, numerous primary schools, not easily quantifiable operate in Nigeria. Non-formal education centres, also require infrastructure, equipment, other resources and of course personnel costs for any meaningful learning to occur. Despite what appears to be a large sum, the actual cost of meeting personnel needs of each education sector is higher when one multiplies costs of the various areas of demand with existing number of educational institutions including the parastatals. The enormity of fund required to keep the education sector at standard can only be imagined. This picture of reality is painted without the figures so that we can be in a better position to objectively appraise the issue of funding of education in Nigeria. Where do the funds come from? What amount or volumes of funds are allocated/available? What is the mechanism for obtaining funds?

\section{Sources of Funding for Education in Nigeria}

Federal Government since 1971 when it took over primary and secondary schools, up to 1975/76 during the period of oil boom had taken the responsibility of taking over from States the management and financing of tertiary institutions. She has remained the major funder of education. It does this through allocation of a percentage of her revenue to education just as it does to other sectors of the economy. It may interest us to know that Federal Government sources of fund are federal taxes, duties on petroleum, profits, court fines, bail funds, exports and imports, Value Added Tax (VAT) on sale of commodities which was introduced in 1996. This VAT is usually shared between the Federal and State government according to agreed formula.

Funds allocated by Federal Government to education sector are normally distributed to the various arms and tiers of education - primary, secondary, tertiary (Universities, Polytechnics and Colleges). State Governments also fund education. Their source is primarily their allocation from the federal account, their share of VAT and State generated revenue through local taxes, school levies etc. Earlier than April 2002, they were not involved in funding primary education when fund meant for primary education was not channelled to States. But since April 2002, States control and started to fund primary education with funds sent specifically for primary education through UBEC. Local Governments are also involved in funding education at the primary school level. Local Government revenues come from statutory allocations from Federal Account, proceeds from VAT and internally generated funds. State Governments through the State Primary Education Boards (SPEB) allocate funds for salaries and other items to Local Government Education Authorities. However, Hinchliffe (2002) reported that some LGA's were able to carry out some capital projects.

Apart from Federal, State and Local Governments funding education there are other sources of funds.

[1] Education Tax Fund: This fund, which was instituted in 1998, stipulates that corporations and companies operating at a certain capacity level, registered in Nigeria should contribute $2 \%$ of their annual assessable profit to the fund. The fund is to be used to augment Federal Government expenditure on education serving especially as fund for interventions in capital projects. The funds are normally given as grants to primary, secondary, and tertiary levels at proportion of 20:30:50.

[2] Multinational Companies such as Shell, Texacco, Chevron etc. also make contributions to education funds as their social responsibility to their host communities. In actual fact, host communities demand that companies operating in their areas fund capital projects such as constructing school blocks, health centres etc. It is also the case that these multinational companies award generous and large scale scholarships to Nigerian students.

[3] International Development Agencies - Agencies such as World Bank, UNICEF, UNESCO, DFID, USAID partnering with Nigeria in development programmes provide funds and/or materials as financial contributions to education sector in Nigeria.

[4] Community Based Funding - Local communities contribute funds and materials to establish and maintain educational institutions especially at the primary and secondary school level. These self-help projects undertaken by communities have not been adequately quantified monetarily. Also, the ParentTeacher Association levies are added fund for education.

[5] Institution Generated Funds - Institutions of learning do generate funds internally through endowments, donations from philanthropists or organizations and from economic/income generating ventures undertaken by them. It is a fact that many Universities augment their expenditure framework with internally generated funds.

From the foregoing, it can be deduced that, education funding comes from different sources. The major one for all levels of government is public revenue from taxation. Education funds are reported to be distributed among the primary, secondary and tertiary education level $\mathrm{s}$ in the proportion of $30 \%$ and $40 \%$ respectively. The 
public funding includes direct government expenditure for teachers' salaries and instructional materials as well as indirect expenditure in the form of subsidies to households such as tax reduction, scholarships, loans and grants. It also includes payment from Education Tax Fund (ETF), mainly for capital expenditure.

Education is supposed to attract considerable portion of public expenditure because of its position as a social service with direct economic significance with generally acclaimed positive spill-over effects. In Nigeria, there is no denying the fact that education is very poorly funded, because it is yet to comply with the UNESCO recommendation that $26 \%$ of annual budget be spent on education. The country spends less than $11 \%$ of her total annual budget on education.

Alternative sources of funding education have been explored. Since 1995, the government established the education tax fund in which companies with more than 100 employees contribute $2 \%$ of their pre-tax earnings to the fund. Primary education receives $40 \%$ of these funds, secondary education receives $50 \%$, primary education has in the past also received funds from the petroleum trust fund for capital expenditure and provision of instructional materials. The fund is currently defunct. Additional funds for primary education are allocated through the National Commission for Nomadic Education and the tertiary education trust fund (TETFUND) which was established as an intervention agency under the TETFUND act of 2011 and saddled with the responsibility for imposing, managing and disbursing the tax money to public tertiary institutions in the country.

The public sector is the major provider and financier of education in Nigeria since it took over most of the schools in the country from primary to tertiary level in the mid 70s. Thus, education has remained one of the most challenging of the seven point agenda enunciated by the Late Umaru Yar'Adua administration on assumption of office in 2007. The administration met an education sector that was in comatose. In spite of the reforms, at best, which were carried out by the immediate past government, there was really nothing on ground to inspire confidence in that very vital segment of our national economy (Nwosu, 2009).

The universities and other tertiary institutions were in a state of advanced decay with most of the teaching staff leaving the country in search of greener pastures abroad. Apart from the impact of inadequate funding on the quality of the teaching and learning process in our institution of higher education, students support is now inadequate. The number of students from poor and disadvantaged background attending our higher institutions has become insignificant. The funding of higher education has been regressive over the years. It was therefore not surprising that the late Yar'Adua's administration had to be confronted by labour unions in the education sector with long lists of demands on what should be done to uplift the sector. The unions, one after the other had to embark on debilitating strike actions to press home their points. The ensuing faceoff between the federal government and academic staff union of universities (ASUU) resulted into the shutting of the universities for close to four months. Furthermore, Imhabekhai and Tonwe (2001) also highlighted that currently universities education at present is underfunded, inadequate funding put the university management under stress and strains hence they are incapacitated in providing essential services. This has led to rampant crises in the system resulting in strikes by academic and non-academic staff, dearth of equipment and facilities, indiscipline among staff and students, upsurge in the activities of secret cults among others. Higher education relates to all forms of post-secondary education such as the universities, polytechnics, colleges of education, monotechnics and professional schools (Abdu, 2003). In the quest for development, developing countries have acknowledged that investment in an adequate funding of higher education are viable, conditions that facilitate change since the value of education hinges on teaching, learning, research and the production of qualified personnel which are needed for national development (UNESCO, 2002).

According to Udoh (2008), Nigeria as a developing nation is currently witnessing increased enrolment of university students. This requires increase in funding which is not the case in Nigeria. Fund allocation does not increase to meet the demand of funds occasioned by the enrolment increase. The unfortunate expectation of both parents and students according to Abdu (2003) are apprehensive of any new initiative in the management of tertiary institution to mean introduction of tuition fees. There still exist difficulties on the higher institutions especially on the universities to meet her only $10 \%$ internal fund generation quote despite the normal government subventions (allocation) to universities. These can only be facilitates through adequate financing.

\section{Volume of Funds Allocated-An Assessment of the Trend}

It has not been easy to have a reliable and comprehensive statistics of amount of funds coming from governments to education sector. Nevertheless available statistics on expenditure for education by federal and state governments which are presented below provides some insight into the realities of funding of education. 
Table 1: Education share of Total Federal Expenditure, 1997 - 2002 (\%)

\begin{tabular}{|l|c|c|c|c|c|c|}
\hline Year & 1997 & 1998 & 1999 & 2000 & 2001 & 2002 \\
\hline Recurrent Fed. Exp. & 12.3 & 12.0 & 11.7 & 9.4 & 9.5 & 9.1 \\
\hline Capital Fed. Exp. & 6.1 & 7.5 & 5.0 & 8.5 & 6.0 & 6.0 \\
\hline Total Fed. Exp. & 9.9 & 9.6 & 9.0 & 9.0 & 7.6 & 8.0 \\
\hline
\end{tabular}

Source: Herbert, 2002.

In 2002 of the Federal governments recurrent and capital expenditure, Education got $9.1 \%$ and $6.0 \%$ respectively, while of the total budget $8.0 \%$ was allocated to education sector. Monies are then allocated to tiers of education. Table 2 illustrates how monies allocated to educational institutions were shared $1996-2002$ ). The situations today have not changed much except for the financial implications of the interpretations of the recently passed UBE bill.

Table 2: Federal Government Expenditure Shared by Levels of Education, 1996 - 2000 (\%)

\begin{tabular}{|l|c|c|c|c|c|c|c|}
\hline Year & 1996 & 1997 & 1998 & 1999 & 2000 & 2001 & 2002 \\
\hline Tertiary & 79.9 & 78.9 & 68.4 & 69.0 & 75.8 & 68.1 & 76.9 \\
\hline Universities & 52.5 & 44.6 & 39.4 & 39.9 & 49.2 & 39.6 & 51.2 \\
\hline Polytechnics & 16.2 & 23.2 & 17.0 & 18.5 & 17.0 & 16.6 & 16.0 \\
\hline $\begin{array}{l}\text { College of } \\
\text { Education }\end{array}$ & 11.2 & 11.1 & 12.0 & 10.6 & 9.6 & 11.9 & 9.7 \\
\hline Secondary & 10.4 & 11.3 & 14.6 & 18.7 & 15.3 & 15.5 & 15.6 \\
\hline Primary & 9.7 & 9.8 & 16.9 & 12.2 & 8.9 & 16.4 & .5 \\
\hline
\end{tabular}

Source: Herbert, 2002.

Table 3: Education Sector Share of the Federal Budget, 1989-2001(in millions)

\begin{tabular}{|l|l|c|c|c|c|c|c|}
\hline & \multicolumn{3}{|l|}{ Federal Government Annual Budget } & \multicolumn{2}{|c|}{ Allocation in Education } & \\
\hline Year & Capital & Recurrent & Total (N) & Capital & Recurrent & Total (N) & $\begin{array}{c}\text { \% of } \\
\text { Total }\end{array}$ \\
\hline 1989 & $9,297.0$ & $208,810.1$ & $30,107.0$ & $221,880.0$ & $1,719.8$ & $1,941.7$ & 6.45 \\
\hline 1990 & $13,451.1$ & $27,208.6$ & $40,660.7$ & $331,746.0$ & 1.872 .9 & 2.204 .7 & 5.45 \\
\hline 1991 & $13,085.4$ & $25,580.5$ & $38,665.9$ & $299,049.6$ & $1,488.5$ & $1,787.6$ & 4.62 \\
\hline 1992 & $15,975.9$ & $36,060.5$ & $52,036.4$ & $395,130.0$ & $1,997.8$ & $2,392.9$ & 4.60 \\
\hline 1993 & $18,116.0$ & $93,500.5$ & $111,616.5$ & $1,563.0$ & $6,436.0$ & $7,999.1$ & 7.20 \\
\hline 1994 & $31,000.0$ & $38,200.0$ & $69,200.0$ & $2,405.7$ & $7,878.0$ & $10,283.8$ & 14.86 \\
\hline 1995 & $44,500.0$ & $56,957.5$ & $111,457.5$ & $3,017.9$ & $9,798.6$ & $12,816.4$ & 11.50 \\
\hline 1996 & $44,477.0$ & $76,744.9$ & $121,221.9$ & $3,215.8$ & $12,135.9$ & $15,351.7$ & 10.81 \\
\hline 1997 & $88,693.0$ & $99,396.2$ & $188,089.3$ & $3,807.9$ & $13,033.2$ & $6,841.2$ & 11.53 \\
\hline 1998 & $129,700.0$ & $116,607.4$ & $246,342.4$ & $9,739.6$ & $13,028.3$ & $23,668.1$ & 9.61 \\
\hline 1999 & $88,000.0$ & $161,000.0$ & $249,000.0$ & $8,291.8$ & $19,421.7$ & $27,713.5$ & 11.13 \\
\hline 2000 & n.d. & n.d. & n.d. & n.d. & n.d. & $56,568, .5$ & 8.70 \\
\hline 2001 & n.d. & n.d. & n.d. & n.d. & n.d. & $62,567.1$ & 7.00 \\
\hline
\end{tabular}

Source: Federal Ministry of Education.

When the allocation is distributed to the various arms and levels of education to meet their various needs, the amount that finally reaches each institution becomes extremely negligible to take care of large work force including academic staff and deteriorating infrastructure. Indeed the story is the same for various educational institutions. Reacting to the allocation 10.5 to $11 \%$ to education, Botswana, Ghana and Namibia allocates $21 \%$, $26 \%$ and $22 \%$ respectively. One must not forget that UNESCO recommended average of $26 \%$ of annual public expenditure to be committed to education in developing countries for at least 10 consecutive years. The sum total of the situation is that Education sector in Nigeria is grossly funded. To some extent the Education Tax Fund has come in as a significant intervening factor helping educational institutions to embark on some of the much needed infrastructure. There is virtually no sector that has not benefited from ETF.

\section{Consequences of Inadequate Funding}

The consequences of this under funding of education sector are known to us and needs to emphasis. Let's start with primary schools. The declaration of Universal Free and Compulsory Basic Education with advocacy 
programmes for enrolment has naturally increased enrolment. The result is that there are insufficient classrooms or no classrooms for pupils, no desks, little or no instructional materials, lack of learning resources such as playgrounds, inadequate number of teachers, many of whom are unqualified to teach, and finally teachers who are owed salaries. I recommend that everyone who has a stake in education visit our primary schools in the villages and get a glimpse of what the learning conditions are like and guess what quality of education pupils are receiving. Do you blame primary school leavers that cannot write correctly a list of names expect perhaps theirs? These are the pupils' transit into secondary schools anyway.

At the secondary school level, the story is not different. Students carry plastic stools to school and sit in crowded classrooms without desks to write upon. Teaching staff strength is low. A school with 2 streams of 6 classes has one Math teacher and one English language teacher. Do we expect that that one teacher to teach all the classes and teach them effectively? Laboratories, where they exist, lack equipment and consumables. The examining bodies devised Alternative to Practical. It is these students who transit into our tertiary institutions. The inadequate preparation of primary and secondary education levels results in huge waste of funds and efforts expended on remedial programmes at higher education.

Dropouts from tertiary institutions are waste of funds. Tertiary institutions where the highest manpower needs are expected to be bred have become places of discontentment by both the lecturers and the students dilapidated infrastructure where infrastructure exist, inadequate learning/teaching facilities such as well-equipped laboratories and workshops etc. It is a fact that in some Universities, first level Chemistry or Biology labs are too small to accommodate the large population of students such as that the students do not get to have the required science practical experiences. Our graduates are described as half-baked by employers and when they go for higher education in foreign countries are subjected to tests and tests to determine the credibility of their certificate. What a shame!! The root of this evil is funding of education and the government of Nigeria knows it and has time after another set up commissions/study groups to find solutions. Among the reports produced are:

- Ogundeko Report (1978) on University Finance

- $\quad$ Cookey Report on Salary and Conditions of Service of University Staff

- Fafunwa Report (1984) on Funding of Education

- $\quad$ Longe Report (1990) on Higher Education

- $\quad$ Etsu of Nupe, Alhaji S. Ndayako (1966/7) on Infrastructure and Education

- Various Visitation Panel Reports

- $\quad$ ASUU Documentation on State of Education Funding

Despite these reports the problem of funding education has persisted. Is it a recurring decimal? Can nothing be done? Should we all watch and see our education system finally collapse? Can we not revisit the recommendation in the reports; try to implement some of them taking into consideration the dynamic nature of education and changes in our social, economic and political situation.

\section{Conclusion}

Education is found to enhance productivity and increase in productivity will in turn entail more training of the manpower that generates the output. The commitment of the federal government of Nigeria to education through her budgetary allocations was found to have little attention been paid to it. However, when the budgetary allocations to education were compared with the $26 \%$ of the total budget recommended by UNESCO for developing countries like Nigeria, it is clear that government has to devote more resources to the sector. Government should increase her budgetary allocation to this sector in a consistent manner because of its great importance to the national economy and growth, hoping that with proper monitoring of fund, it would contribute more significantly to the development of the country. An effective utilization of such fund is also advocated and all areas of wastage blocked. All organs of the government should exhibit good corporate governance and transparency. Lack of corporate governance and transparency have been the problems of successive governments and attempts to curb incidences of fraud and misappropriation of funds by the establishment of bodies such as the economic and financial crimes commission (EFCC) and the independent corrupt practices and other related offences commission (ICPC) seem not to have made the desired impacts judging from the number of reported cases and the concluded ones. These institutions should be strengthened and given more powers to dispense with cases speedily.

\section{REFERENCES}

Ajibade, E. S. (1988). Funding Higher Education in a Period of Political, Social and Economic Stress: A Case for Nigeria in 13.0. Ukeje, B. S. Okeke, Ehaohwo, S. Ariweriokuma \& P.O.M. Nnabuo (Eds) Crucial Issues in 
Education: The Case of Nigeria (pp. 74-78). Port Harcourt: NAEAP Publication/Pam Unique Publishing Company.

Dike Victor (2001). The State of Education in Nigeria and the Health of the Nation: In Africa Economic Analysis.

Ekong, Grace (2003). Cost and Financing of Education in Education Today, 19(1), 1-2.

Fagbul, Iyabo (2003). Cost and Financing of Education in Education Today, 19(1), 2-5.

Federal Republic of Nigeria, National Policy on Education (Revised 2004). Yaba: NERDC Press.

FGN (2004). Understanding Budget 2004, Abuja.

FME (1991). Higher Education in the Nineties and Beyond. Report of Eonge Commission on the Review of Higher of Education in Nigeria, Abuja.

FME (1997). Committee on the future of higher education in Nigeria, Vol. 3 (Elsu Nupe Committee Report).

FME (2002). The Financing of Education in Nigeria. Education Sector Analysis of FME. The World Bank and DFID, Abuja.

FME (2002). Plan of Action on the Resolutions of the National Summit on Higher Education, Abuja.

FME (2003). Education Sector Status Report, in collaboration with UNESCO, Abuja, FGN (2004). Understanding Budget 2004, Abuja.

FME (1991). Higher Education in the Nineties and Beyond. Report of Eonge Commission on the Review of Higher of Education in Nigeria, Abuja.

FME (1997). Committee on the future of Higher Education in Nigeria. Vol. 3 (Elsu Nupe Committee Report).

FME (2002). The Financing of Education in Nigeria, Education Sector Analysis of FME. The World Bank and DFID, Abuja.

FME (2002). Plan of Action on the Resolutions of the National Summit on Higher Education, Abuja.

FME (2003). Education Sector Status Report, in collaboration with UNESCO, Abuja.

HinchlifTe Keith (2002). Public Expenditure on Education in Nigeria: Issues, Estimates and Implications. Africa Region of Human Development Working Paper Series, The World Bank.

Maduewesi, E. J. Financing of Education in Nigeria. Nigerian Academy of Education Year Book, No. 3, NAE.

NUC (2005). 2003 Appropriation Act and 2004 Appropriation Act, Abuja.

Nwagwu, N. A. (2000). "Funding and Financial Management in Nigeria Tertiary Institutions" In Okeke E.A.C. (ed) Improving Effectiveness and Efficiency on the Management of Today's Tertiary Institutions.

Obanya, P. A. I. (2001). Financing the Universal Basic Education (HUE) Programme in Maduewesi, E. J. (3d). Financing of Education in Nigeria, Nigeria Academy of Education.

Obocgbunani, A. I. (2005) constraints to Voluntary Agency Participation in the Finding of Secondary Schools. In G. O. Akpa, S. U., Udoh, \& E. O. Fagbamiye (Eds). Deregulating the Provision and Management of Education in Nigeria (pp. 194-198) Jos: NAEAP Publication.

Ogbormaya, N. I. (2000). Foundations of Education Finance. Cape Publishers Ltd., Onitsha.

Ocho, L. O. (2004). "Sources of Finance for Education in Nigeria". An Invited Paper Presented at the Stakeholders Workshop held at Owerri. 
Okebukola, Peter (2003). Funding University Education in Nigeria in Education Today, 10(1), 27-32.

Okunamiri, P. O. (2001). Provision and Management of Education Finance in Nigeria. In N. A. Nvvagwu, E. T. Ehiamctalor, M. A., Ogunu \& Mon Nwadiani (Eds) Current Issues in Educational Management in Nigeria (pp. 230-251). Benin City: NAEAP Publication.

Okunamiri, P. O. (2002). Resourcing and Guidelines for Educational Finance in Tertiary Institutions in Nigeria (.pp. 1-21). Okigwe: Fasmen Communications. 